\title{
SLATE
}

The University of Illinois announces the establishment of a multidisciplinary Ph.D. program in Second Language Acquisition and Teacher Education (SLATE). SLATE is supported by faculty from ten different departments. Applicants for admission must have a Masters Degree in an appropriate related field (TESL, Linguistics, Foreign Language, Education, etc.). Course from many different departments are avilable to each SLATE student. Dissertation research can be done in areas such as interlanguage syntax, phonology and discourse, cognitive and affective factors in learning and teaching, communication strategies, computer-assisted instruction, and curriculum and test design. The program usually requires three to four years of work beyond the Masters Degree.

For more information write to:

Professor Sandra J. Savignon

SLATE Chair

University of Illinois

707 South Mathews, Room 2090

Urbana, IL 61801 


\title{
American Association for Applied Linguistics
}

Secretary-Treasurer's address:

\author{
Albert Valdman \\ CREDLI \\ Ballantine Hall 602 \\ Indiana University \\ Bloomington, IN 47405
}

The American Association for Applied Linguistics is a professional association of scholars who are interested in and actively contributing to the multidisciplinary field of applied linguistics. Founded in 1977, AAAL promotes research, facilitates the distribution and exchange of information, and organizes scholarly conferences and meetings. AAAL actively cooperates with other related associations:

- AAAL holds an annual conference in conjunction with the Linguistic Society of America.

- AAAL is the U.S. affiliate of the International Association of Applied Linguistics (AILA).

- AAAL cooperates in producing publications with the Center for Applied Linguistics, such as the International Directory of Applied Linguistics Organizations, and special articles on linguistics and the professions.

- AAAL jointly sponsors, with the British Association for Applied Linguistics, the journal Applied Linguistics.

In addition, AAAL publishes a member's newsletter three times a year, which includes membership lists, preliminary programs of annual meetings, publication notices, and conference reports.

Membership in the Association is on a calendar-year basis and costs $\$ 10$ a year. Back issues of the newsletter will be sent. 


\section{Application for AAAL Membership}

Complete this form and send it to the AAAL Membership Office at the address below. Please enclose a check or money order for $\$ 10$. Back issues of the newsletter for this calendar year will be sent.

Name

Address

Zip

Signature Date

American Association for Applied Linguistics 3520 Prospect Street NW

Washington, D.C. 20007 

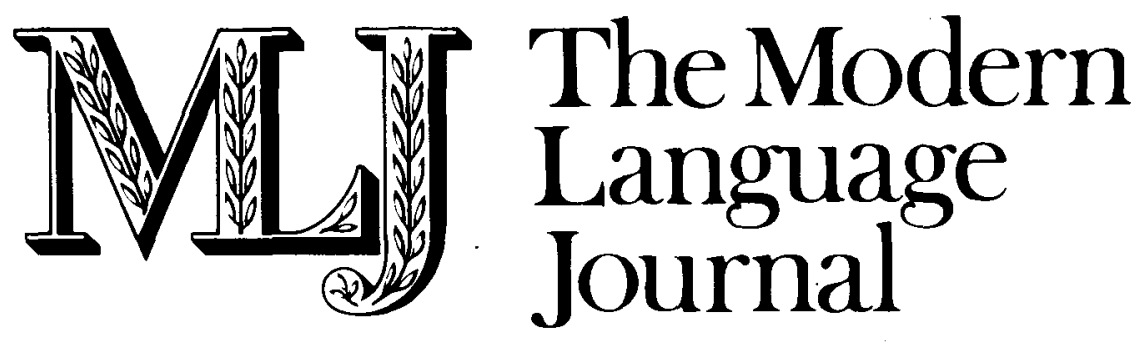

Founded: 1916

Editor: David P. Benseler

Dept. of German

Ohio State University

Columbus, $\mathrm{OH} 43210$

... is recognized throughout the world as the outstanding foreign language/pedagogical research journal in the United States. This popular journal was founded in 1916 by the National Federation of Modern Language Teachers Associations. Topics covered in MLJ include teaching strategies, bilingualism, applied linguistics, teaching of literature, study abroad, innovative foreign language programs, and developments in curriculum, teaching materials, and testing and evaluation.

ISSN 0026-7902

\section{Published quarterly at The University of Wisconsin Press}

Subscribe now, or recommend a subscription to your library. A detailed brochure will be sent upon request.

RATES

Individuals: $\$ 13 / \mathrm{yr}$.

(must prepay)

Institutions: $\$ 30 / \mathrm{yr}$.

Foreign subscribers add $\$ 3 / \mathrm{yr}$.

for regular postage, or $\$ 12.50 / \mathrm{yr}$.

for Airmail delivery.
REPLY TO

Journal Division

The University of Wisconsin Press

114 North Murray Street

Madison, Wisconsin 53715

USA

(608) $262-4952$ 


\section{Studies in Descriptive Linguistics}

General Editor: Dietrich Nehls

Vol. 11

Papers on Language Acquisition, Language Learning, and Language Teaching

By Henning Wode

1983, VIII/272 pages, paper, ISBN 3-87276-260-5

DM 59,-

This volume brings together a number of papers written between 1970 and 1980 . One of the major concerns throughout these papers is to show that learning a foreign language in the classroom via foreign language teaching is by no means totally different from mastering a language in natural situations. Thus, foreign language teaching has to be integrated into a comprehensive view of language learning which includes all types of language acquisition.

Part I: An Integrated vlew of language learning - Naturalistic L2-Acquisition: Issues, Goals and Perspectives / Focus on the Student: Foreign Language Teaching from the Learner's Point of View.

Part II: Language Learning and Cognition - Some Stages in the Acquisition of Questions by Monolingual Children / Four Early Stages in the Acquisition of L1-Negation / Grammatical Intonation in Child Language.

Part III: The Nature of Language Development - Developmental Sequence: An Alternative Approach to Morpheme Order / On the Usefulness of Experimental Elicitation Techniques for Investigations on Naturalistic L2-Acquisition.

Part IV: Interlanguage Strategies - Operating Principles and 'Universals' in L1, L2 and Foreign Language Teaching / On the Systematicity of L1-Transfer in L2-Acquisition / The Beginning of Non-Schoolroom L2-Phonological Acquisition.

Part V: Universals - Language Acquisition, Pidgins and Language Typology I Phonology in L2-Acquisition.

Part VI: Towards an Integrated Theory of Language Acquisition - An Integrated View of Language Learning / Contrastive Analysis and Language Learning.

\section{Sole distribution}

USA and Canada, Middle and South America : John Benjamins North America, Inc., Publisher, One Buttonwood Square, 202, Philadelphia/PA. 19130/USA

Southern Africa: Universitas Books (Pty.) Ltd., P.O. Box 1557, 0001 Pretoria, South Africa Australia: River Seine Publications Pty. Ltd., 132 Elgin Street, Carlton, VIC. 3053, Australia

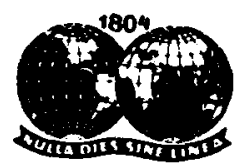

\section{JULIUS GROOS VERLAG Postfach 102423 - D-6900 Heidelberg 1}


Journal

of

Literary

Semantics

\section{An International Review}

ISSN 0341-7638
Editor: Trevor Eaton

Academic Headquarters:

Language Centre, University of Kent at Canterbury/England

The aim of the Journal of Literary Semantics is to concentrate the endeavours of theoretical and applied linguists upon those texts traditionally classed as 'literary' in the belief that such texts are a central, not a peripheral, concern of linguistics.

The journal publishes articles on all aspects of literary semantics; articles of a philosophical nature attempting to relate the study of literature to other disciplines, such as psychology, neurophysiology, mathematics, history; articles dealing with the educational problems inherent in the study of literature.

The journal will also publish reviews of books whose subject matter is germane to literary semantics. Books for review should be sent to the Editor.

J.L.S. appears in annual volumes, each volume consisting of three issues, appearing in April, August and October.

Subscription per volume Single copies

Back volumes (Nos. I-X)
DM 64,-

DM 27,-

DM 40,-

\section{Sole distribution}

USA and Canada, Middle and South America : John Benjamins North America, Inc., Publisher, One Buttonwood Square, 202, Philadelphia/PA. 19130/USA

Southern Africa: Universitas Books (Pty.) Ltd., P.O. Box 1557, 0001 Pretoria, South Africa Australia: River Seine Publications Pty. Ltd., 132 Elgin Street, Carlton, VIC. 3053, Australia

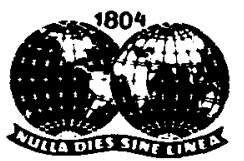

JULIUS GROOS VERLAG Postfach 102423 - D-6900 Heidelberg 1 


\section{Research Notes}

Researchers are invited to submit "brief" reports on current completed research of relevance to second language acquisition (maximum length 10 double-spaced pages). Research articles should be double-spaced, conform to the Studies in Second Language Acquisition format, and should include the following: author's name, affiliation, address, short abstract, and title of the research project. Send two copies to:

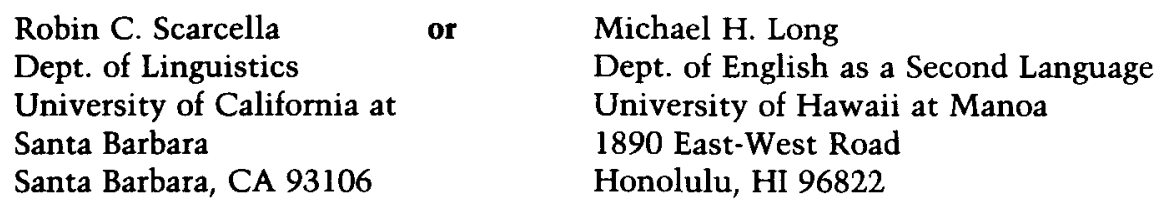

Forthcoming in the next issue (Vol. 6, No. 2), to appear in Spring 1984:

\section{Articles}

Russell S. Tomlin

The Treatment of Foreground-Background Information in the On-Line

Descriptive Discourse of Second Language Learners

William Frawley \& James P. Lantolf

Speaking and Self-Order: A Critique of Orthodox $\mathrm{L}_{2}$ Research

Helmut Zobl

The Wave Model of Linguistic Change and the Naturalness of Interlanguage

The following colleagues have kindly consented to review submissions to SSLA in the course of the last year. It is the policy of SSLA to have each submission evaluated by three consultants, at least two of whom are not on the staff of Indiana University. This extensive reviewing process guarantees maintenance of the quality of the journal, and the Editors owe a great debt of gratitude to colleagues who have conscientiously and thoroughly examined submitted material, in many instances made valuable editorial suggestions, and responded promptly. Diane Birckbichler, Marina K. Burt, Eneida Chaves, S. Pit Corder, Suzanne Flynn, Stephen Gaies, Susan Gass, Edith Hanania, Beverly Hartford, Evelyn Hatch, Stephen Krashen, Robert Lafayette, John Oller, Eta Schneiderman, Thomas Scovel. 


\section{IN THIS ISSUE}

\section{Articles}

James W. Tollefson, Bob Jacobs, \& Elaine J. Selipsky

The Monitor Model and Neurofunctional Theory: An Integrated View

Roberta Abraham

Relationships Between Use of the Strategy of Monitoring and Cognitive Style

Thom Huebner

Linguistic Systems and Linguistic Change in an Interlanguage

\section{Research Notes}

Robert L. Politzer

An Exploratory Study of Self-Reported Language Learning Behaviors and Their Relation to Achievement

Teresa Pica

Methods of Morpheme Quantification: Their Effect on the Interpretation of Second Language Data

N. Ann Chenoweth, Richard R. Day, Ann E. Chun, Stuart Luppescu

Attitudes and Preferences of ESL Students to Error Correction

\section{Review Articles}

Bruce Smith

John C. Catford, Fundamental Problems in Phonetics

Tina Raffaldini

Richard D. Lambert \& Barbara Freed, The Loss of Language Skills

\section{Reviews}

Robert J. Di Pietro

C.J. Brumfit \& J.T. Roberts, An Introduction to Language and Language Teaching

William D. Keel

Walter F.W. Lohnes \& Edwin A. Hopkins (eds.), The Contrastive Grammar of English and German

Quentin Pizzini

Milton M. Azevedo, Contrastive Phonology of Portuguese and English

John R. Gutierrez

Joshua A. Fishman and Gary D. Keller (eds.), Bilingual Education for Hispanic Students in the United States

Saville-Troike, Muriel

F. Barkin, Elizabeth Brandt, and Jacob Ornstein-Galicia, Bilingualism and Language Contact

\section{Publications Received}

